[Vicino Oriente XVII (2013), pp. 21-38]

\title{
SASANIAN AND EARLY ISLAMIC SETTLEMENT PATTERNS NORTH OF THE PERSIAN GULF
}

\author{
Ahmadali Asadi ${ }^{1}$ - Seyed Mehdi Mousavi Kouhpar ${ }^{2}$ - \\ Javad Neyestani ${ }^{3}$ - Alireza Hojabri-Nobari ${ }^{4}$ - \\ Tarbiat Modares University
}

Le recenti ricognizioni archeologiche effettuate nella regione prospiciente la costa settentrionale del Golfo Persico hanno rivelato una significativa crescita degli insediamenti in epoca sasanide. Tale crescita è probabilmente da attribuire ad un mirato investimento nei sistemi d'irrigazione e nell'agricoltura.

Nel corso delle ricognizioni sono stati scoperti resti di diverse strutture idrauliche, quali canali, mulini ad acqua, qanat e pozzi. La gran parte degli abitati sono situati nelle zone pedemontane ed in questi casi le opere idrauliche si trovano spesso nelle aree alte degli insediamenti. In alcuni casi sono stati identificati anche dei cimiteri. In conclusione si può dire che l'economia del Fars meridionale di epoca sasanide era basata sull'agricoltura ancor più che sul commercio e la rete di strade di comunicazione.

Keywords: Fars; Sasanian; irrigation system; settlement; fortified sites

\section{PREMISE}

There has been little research into the effect the Sasanian Empire's collapse had on settlement patterns in the Iranian plateau. The general hypothesis is that the economic system remained unchanged after the Islamic invasion (664 CE) and some researchers even contend that the economic system improved. ${ }^{5}$ Recent archaeological surveys, in the hinterlands north of the Persian Gulf, are throwing light on some interesting new information regarding this matter. The results from most of these surveys in the hinterland, share a common feature - they illustrate the expansion of sites during the Sasanian period and the reduction, and in some cases disappearance, of sites after the arrival of Islam. One could conclude from these recent surveys, that new settlement patterns emerged during the Islamic period due to the disappearance of settlement patterns particular to the Sasanian dynasty. In this paper we will be looking in detail at Sasanian policy in relation to economic investment in the hinterlands north of the Persian Gulf. Archaeological evidence suggests that there was huge Sasanian investment in agriculture and an extension of irrigation in the mountainous areas south of Fars province. However, the development of agriculture in the aforementioned area differs from what the Sasanians did in the Susiana plain $^{6}$ and Mesopotamia. ${ }^{7}$ In these regions huge dams and massive irrigation channels

PhD Student in Archaeology, Tarbiat Modares University.

Assistant Professor, Department of Archaeology, Tarbiat Modares University.

Assistant Professor, Department of Archaeology, Tarbiat Modares University.

Associated Professor, Department of Archaeology, Tarbiat Modares University.

Whitcomb 1979, 5; Sumner - Whitcomb 1999, 314.

Wenke 1981 
(some of which remain standing today) allowed the Sasanians to develop agriculture on a large scale. In the mountainous region however the situation was different. There were neither large plains nor big rivers like the Euphrates, Karoun or Tigris. It appears that Sasanian agricultural policy in the mountainous regions constituted a small investment on a large scale. To reach this aim, governmental control and presence was a necessity. After the collapse of the Sasanian dynasty this agricultural system was no longer sustainable. Using archaeological evidence from recent surveys in various areas north of the Persian Gulf, we will now look in more detail at settlement patterns, the factors affecting it, and the changes after the Islamic period.

\section{GEOGRAPHICAL SETTING OF THE HINTERLANDS AND ITS IMPLICATIONS}

Due to the differences in the geographical and climatic settings between the Persian Gulf hinterlands and northern and central region of Fars province varied settlement patterns are witnessed through time. The climatic situation in the hinterlands is variable and the environment played a key role in deciding how and where human settlements were established. A survey of the hinterlands shows that natural factors such as poor rainfall, salty plugs and rivers, mountains, variable climate and access to a suitable water supply play an important role in how and where human settlements were established.

As one moves south, the Zagros Mountains change direction from north west/south east to an east/westerly direction, particularly as we get closer to Larestan and Bander Abbas. It is significant that in the area known as Tangestan the Zagros highlands rise immediately from the Persian Gulf and there is no intervening coastal plain. Ridges front much of the coast in parallel ranks producing a closed coastline devoid of indentations that could serve as harbours and the small size of rivers and their deeply indented valleys greatly reduce the possibility of agriculture and the occurrence of natural pasture. Poor in resources without major routes that could assist development, Tangestan has only scanty settlements that produce dates, a little millet and barley any vegetables. ${ }^{8}$ Eastwards again, fronting the reentrant of the Gulf of Hormuz, is a geographically distinctive region whose relief is much influenced by the presence of numerous salt domes or plugs that have erupted from a considerable depth through overlying strata. ${ }^{9}$ As a semi plastic substance, the salt has been forced through overlying rock formations and some plugs now stand at heights of 2000 to $4000 \mathrm{ft}$ above the surface (fig.1), appearing as pinkish-white or yellowish masses. ${ }^{10}$ The salt itself has little if any commercial value, and the extra salinity imparted by drainage from the areas where the plugs occur is a considerable disadvantage - Rudshur (or Rud-i-Shur) means "Salt River". ${ }^{11}$ In some places an original salt plug may have been eroded away so that the rocks have fallen back into the solution hallow, producing a chaotic local landscape of jumbled rock strata and irregular topographic outlines. ${ }^{12}$ Moving to the east, the sudden

\footnotetext{
Adams 1965.

Fisher 1968, 30.

Fisher 1968.

Fisher 1968.

Fisher 1968, 31

12 Fisher 1968.
} 
change in direction of the present-day coastline, which now runs north-eastward from Bandar-e Lingeh means that, in sharp contrast to the area west and north of Lingeh (including Tangestan), the component ridges of the Zagros are aligned at right angles to the coast, which is consequently much more accessible and "open", with better harbours. A number of coastal settlements have thus grown up, with distinctly larger numbers of people than in the area farther west. ${ }^{13}$

The most striking factor separating the southern Zagros area from the others is that of climate. Rainfall is very much lower compared with the northern and middle regions of the Zagros with, consequently, major changes in the nature of topography and in human responses. Besides a reduction in overall amount, rainfall tends to be distinctly more unreliable and sporadic in onset, with a tendency to heavy but short falls and irregularity both in season and from year to year. ${ }^{14}$ In these areas, irrigation systems dominate the layout of cultivation, with ditches fed by springs. Qanats too are important and in areas of lower altitude, where temperatures can be very high, covered tanks and pools are increasingly used. ${ }^{15}$

The unfavourable natural settings in coastal and hinterland sites reduced the possibility of establishing human settlements in these areas. Before the formation of empires, settlement patterns in the hinterlands were dependant mainly on access to water sources from springs and wet gorges. In historical periods too, much of the archaeological evidence such as ancient water storage structures and irrigation systems in the hinterlands areas, shows that the water supply has been the main problem for human life in the discussed areas. Due to the saltiness of the rivers, particularly in the downstream areas, nowadays, there is no human settlements close to the rivers and according to the distribution maps of ancient sites, it seems that this situation is the same as today as it was in the past. ${ }^{16}$ The only lands that provide favourable conditions for the establishment of settlements are the foothills, between the rivers and the mountains. ${ }^{17}$ As we will see in this paper, most of the ancient settlements of the hinterlands were founded in these areas.

\section{PREVIOUS RESEARCH}

For researchers of the Sasanian period the Persian Gulf has always been an important topic, especially in relation to Sasanian maritime trade. Scholars such as Whitehouse and Williamson, ${ }^{18}$ Daryaee, ${ }^{19}$ Moussavi and Khosrozadeh $^{20}$ have written on this subject. However, their research of archaeological evidence is devoid of sufficient reference to the hinterlands. This is due to the lack of adequate surveys of the hinterlands before or during their research. The first research into the hinterlands was carried out by some of the agents

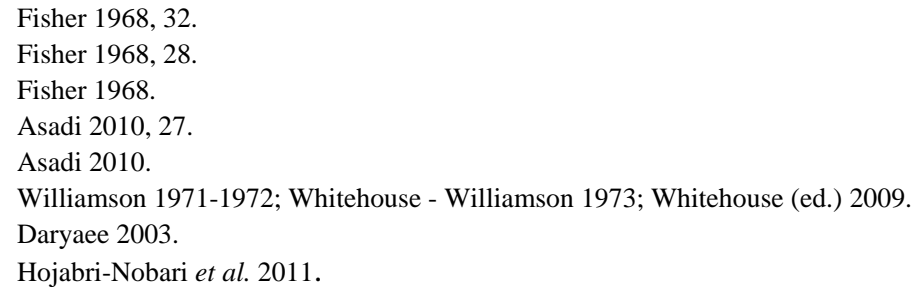


of the East India Company in 1850, followed by Stein ${ }^{21}$ in 1937. After a long hiatus research was resumed in the Bushehr plain first in 1970 by Prickett and Williamson ${ }^{22}$ and then by Whitcomb ${ }^{23}$ in 1973. In 1973 a joint survey was undertaken by the Siraf excavation mission and the Iranian archaeological Center in the Siraf Hinterlands. ${ }^{24}$ Thirty years later, new surveys were initiated by the Iranian Center for archaeology with the aim of completing the archaeological map of Iran. The most recent surveys were carried out in 2004 in the Lar and Lamerd districts by Askari, ${ }^{25}$ the Bushehr hinterlands by Carter and others in 2006, ${ }^{26}$ Bastak district by Asadi ${ }^{27}$ in 2007 and Ghavbandi district by Askari in $2007 .{ }^{28}$ The new surveys seem to provide a more precise understanding of settlement patterns during the Sasanian period in the south of Fars province. In the rest of this paper we will study the results of these surveys in finer detail, however the interpretations put forth here are preliminary and need to be reviewed in the near future.

\section{BUSHEHR DISTRICT}

The Bushehr plain is the most westerly point of the present research area. Compared to the eastern areas, like Lamerd, Mohr and Bastak, the Bushehr plain is geographically and environmentally different, it is rare in that it is one of only a handful of fertile plains in the coastal lines of the Persian Gulf. Rivers flow through the plain today and unlike most of the other hinterland areas where salty rivers prevent human settlement being established in their vicinity, here, the major settlement was concentrated along the rivers. ${ }^{29}$ Even though today some of the rivers have become salty, they are still used for planting dates, palm trees and grains.

The Bushehr peninsula and its hinterlands were surveyed by a joint Iranian/British archaeological team in 2004, with the aim of identifying the nature of the Persian Gulf hinterland settlements and making a chronological and cultural framework for the region. ${ }^{30}$ The survey included areas between Bushehr, Genaveh, Ahrom and Daleki (fig. 2) covering $90 \mathrm{~km}$ from the northwest to the southeast and $60 \mathrm{~km}$ from the northeast to the southwest. ${ }^{31}$ In this survey 56 sites were identified from Chalcolithic (5000 BC) to the late Islamic (15 - $18^{\text {th }}$ century). Most of the sites however belonged to the Achaemenid through to the Sasanid eras. ${ }^{32}$ The results of the survey point to the Elamite period, with ten identified sites, being the first major expansion of settlement in the region. perhaps on account of the

1 Stein 1937

22 Prickett - Williamson 1970.

23 Carter et al. 2006, 67.

24 Whitcomb 2009, 95.

25 Askari Chaverdi - Azarnoush 2004.

26 Carter et al. 2006.

27 Asadi 2010.

28 Askari Chaverdi 2008.

29 Carter et al. 2006, 75.

30 Carter et al. 2006, 63.

31 Carter et al. 2006, 68.

32 Carter et al. 2006, 64. 
middle Elamite centre at Liyan. ${ }^{33}$ After the Elamites, the next large growth of settlement was in the Achaemenid/Parthian period, with 32 sites. ${ }^{34}$ The importance of the Bushehr plain during the Achaemenid era is illustrated by the number of Achaemenid palaces found in the area. In the subsequent Sasanid era 36 sites are found, heralding the peak of settlement in the region. ${ }^{35}$ With the arrival of Islam we see a very marked decline in settlements in the region with nine Islamic sites being found in the plain. ${ }^{36}$

Sasanian settlements are mostly concentrated southeast of the Dalki River (fig. 3). According to the surveyors, including Carter, «most of the sites with Achaemenid/Parthian pottery also bore Sasanian material». ${ }^{37}$ They also mention that while the classes associated with the Achaemenid/Parthian pottery may have also been used during the Sasanid period, many of the sites currently assigned to the Achaemenid/Parthian and Sasanian horizons may date solely to the latter. ${ }^{38}$ The most important Sasanid sites, a complex of mounds located north of Borazjan, are recorded in Carter's survey as site numbers BH29-44. Carter interpreted these as remains of a Sasanid city. There are also more Sasanid sites circling BH29-44. ${ }^{39}$ Without doubt, the Sasanid port of Rav Ardeshir located in the Bushehr peninsula was the most important factor affecting the growth of settlements in the Bushehr hinterlands. In his survey with Martha Prickett between 1969-1971, Williamson concluded that Rishahr, a site $6 \mathrm{~km}$ south of Bushehr, was the Sasanian port Rav Ardeshir. ${ }^{40}$ According to historical sources, Rav Ardeshir was one of the foremost ports during the Sasanian era, and it was established by Ardeshir Babakan as part of his policy for control of maritime trade in the Persian Gulf. ${ }^{41}$ The size of Pre-Islamic settlements in the Bushehr peninsula was remarkable, with some researchers estimating the dimensions to be over 450 hectares, ${ }^{42}$ with most belonging to the Sasanid era. Using Carter's Sasanian distribution map, we can assume that the Sasanian city situated north of Borazjan (BH29-44) played a central role and that it was of significance for the Rave Ardeshir port, situated as it is in the centre of so many other Sasanid sites. Carter writes «Bushehr may well have acted primarily as a port and entrêpot. The inland town lay within the heart of an agricultural landscape surrounded by other Achaemenid to Sasanian sites, some of which also attained considerable proportions. The town may have been highly significant in coordinating the provision of subsistence or surplus commodities to Bushehr and the redistribution of goods from the port to the major centres in inland Fars». ${ }^{43}$ The destruction of Rave Ardeshir




during attacks by invading Arabs was catastrophic for the city, and archaeological evidence points to the port and city being abandoned simultaneously. ${ }^{44}$

The symbiotic relationship between the city and port dates back to before Sasanid times. As previously noted, using Carter's site maps (fig. 3) it becomes clear that the distribution of Sasanian sites in the Bushehr plain is similar to Achaemenid/Parthian site distribution. ${ }^{45}$ It appears that before Sasanid Rave Ardeshir there was a pre-existing port serving the Bushehr peninsula. Whitehouse and Williamson speak about a possible Achaemenian port on the southern most edge of the peninsulas. ${ }^{46}$ If we accept the existence of an Achamenian port in the peninsula one can postulate the importance of this port for the expansion of Achaemenian/Parthian settlements. It is possible to find the name of the city that supported the port during the Achamenian and Sasanian periods, using Islamic, Roman and Pahlavi written sources. Nearkhos, Alexander's admiral (330 BC), mentions a city named Taoxn in his travelogue 'from Sind to Tigris'. Taoxn was located close to the river Granis, which also had a Persian royal palace situated nearby (Arrian, VII: 421). Later on, the Pahlavi text 'Shahrestanhaye Iran' (Iranian towns), refers to a city in the Bushehr plain named Touzak, and finally, in the Islamic sources the name Tavaj appears. ${ }^{47}$ We can assume that the names 'Achamenian', 'Taoxn', 'Sasanian', 'Touzak', and Islamic 'Tavaj', were one and the same with a slight alteration in the location of the city.

Donald Whitcomb, using aerial photography in 1973, writes about an old canal dating back to the Achaemenian period, which Carter and his team did not locate in $2004 .{ }^{48}$ As we will see later in the paper, the Sasanians established a large network of irrigation canals and structures in the hinterland valleys. Due to the fertility of the soil in the Bushehr plain there must be more structure related to farming. In addition, when considering the agricultural systems put in place by the Sasanian empire elsewhere, there is surely a need for more intensive surveys to locate Sasanian irrigation systems in the Bushehr plain. In their 2004 survey, Carter and his team also attempted to reconstruct some of the roads between the Bushehr plain and the interior of Fars province. ${ }^{49}$ Due to the importance of Rav Ardeshir during the Sasanian period, there must have been a busy communication route to the north, which may have passed many Sasanain sites. It was perhaps the only important road to inland Fars throughout the entire Persian coastline from Bushehr to the Hormoz strait.

\section{SIRAF PORT}

The hinterlands of Siraf port was researched in 1973 by an Iranian/British team led by Whitcomb (fig. 4). They surveyed the eastern part of Jam valley, the western end of Galehdar valley, and the road between Jam valley and the Dejgah valley. ${ }^{50}$ Whitcomb's research was centred on the nature and limit of settlements in the early Islamic period $\left(9^{\text {th }}\right.$ -

44 Carter et al. 2006, 97.

45 Carter et al. 2006, 66.

46 Whitehouse - Williamson 1973, 35.

47 Kianrad 2005, 108.

48 Carter et al. 2006, 67.

49 Carter et al. 2006, 96.

50 Whitcomb 2009, 78 
$11^{\text {th }}$ century) when Siraf was of great importance and famous for trade but he also noted some Sasanid sites. ${ }^{51}$ Whitcomb's results from the 1973 survey indicate that the road between Siraf and the north - especially from Jam to the Dezhgah - was full of caravansary and water storage facilities. ${ }^{52}$ In contrast he noted that there were no structures related to this road in Galehdar. Instead, he writes about fortified sites which differed from the Siraf structures in Galehdar. ${ }^{53}$ In the chronology he defined one site in Galehdar, one in Jam and three sites in the valley as Sasanid, a further three sites - two in Jam and one in Dejghah he attributed to the Sasanid and early Islamic period. ${ }^{54}$ Of all of these Sasanian sites, five are located on mounds with a height of 50 meters or more, ${ }^{55}$ which leads one to believe that more intensive surveys in this region could discover more Sasanid sites. In the trade roads from Siraf port to the north there are no concentrations of Sasanid sites as is witnessed in the early Islamic period. This, as Whitehouse says, is because in the Sasanid period Siraf's port was more important for military purposes, ${ }^{56}$ and, naturally trading ports (as Siraf was in the Islamic era) require more supporting related settlements and structures. It seems that the economy of the valleys behind Siraf, like Lamer and Bastak (as we will see later), during the Sasanid era was possibly related more to the control of agriculture in the interior settlements.

\section{LAMERD, MOHR AND DARO-LMIZAN VALLEYS}

Lamerd and Mohr districts are the natural continuation of the Galehdar valley to the east, and to the north Alamard dasht district runs parallel to Lamerd and Mohr (fig. 5). Three perennial rivers, Mehran, Alamard dasht and Darolmizan, flow through these plains. The first research in these plains was undertaken by Stein ${ }^{57}$ and Heinz Gaube ${ }^{58}$ who discovered more than thirty sites in these plains. ${ }^{59}$ Whitcomb, in his 1973 survey of the hinterlands of Siraf, also included Galehdar valley in his research, locating fifteen further sites. ${ }^{60}$ The most extensive survey, carried out by Askari Chahverdi between 1998-2001, located forty-three sites. With the sites discovered by Stein and Gaube, Askari argues that the total number of sites in the valleys was seventy-six. ${ }^{61}$ Some of the sites discovered by Askari in Galehdar may overlap with those discovered by Whitcomb, whose research had not been published when Askari undertook his survey. Of a total of seventy-six sites and mounds, four are Achaemenid, twelve are Parthian and thirty are Sasanid. In terms of site type, fifteen are Sasanid structures including architectural, water storage and a building for




burials. ${ }^{62} \mathrm{~A}$ total of fifty sites were identified which date to the Islamic period (this is due to reuse of sites in different eras), of which nineteen dated back to the early Islamic period. ${ }^{63}$ According to the survey report by Askari, during the period of Sasanid rule, there is an increase in the population in areas that were already populated and settlements were also established in the foothills to the south and southeast of the area surveyed, where before there had been no habitation. ${ }^{64}$ There are three times more sites in the Sasanid era as compared to the Parthian period and a ten-fold increase compared to the Achaemenid era. ${ }^{65}$ This is without considering the fifteen structures found outside settlements and mounds. ${ }^{66}$ The increase in sites during the Sasanid period when compared with previous eras is remarkable (fig. 6). If we look at the site distribution map it is clear that prior to the Sasanid era most settlements were in the foothills where habitation conditions are favourable, however after the Sasanid era the settlements are found all over the valley, even where there are less favourable conditions for habitation. ${ }^{67}$ The archaeological evidence illustrates the advanced nature of Sasanid irrigation techniques and land management, which made possible for them to increase settlements in such large numbers. The remains of irrigation systems are reported everywhere close to Sasanid sites. Some of the Sasanid sites would not have been habitable had water not been transferred from remote gorges. One could postulate that there was a degree of forward planning and the irrigation systems predated and made possible the appearance of multiple sites across the valley. It seems that better use of land and water was a policy of central government. Askari, in his report, writes about twenty fortified Sasanid sites, which are located near the settlements in the foothills of the plains. $^{68}$ These fortified sites are without doubt a sign of governmental presence in the region, and their role could include collection of taxes, provision of security and management advice (especially for developing irrigation systems). Askari argues that the increase in settlements in the valleys is also associated with trade from Siraf port, ${ }^{69}$ however, during the Sasanid era Siraf port was mainly a military base (it became an important trading port during the early Islamic era) and the authors do not believe the increase in sites to have been affected by the presence of this military base during the Sasanid era. Furthermore, the areas surveyed by Askari were not on the trade routes to the north. In conclusion the increase in sites in the Lar, Lamer and Darolmizan valleys (surveyed by Askari) is due to an increase in agriculture supported by central government.

\section{BASTAK DISTRICT.}

The Bastak district (located to the east of Lamer) is the final district to be discussed in this paper. Geographically Lamer and Bastak are very similar. The Bastak district is

\footnotetext{
Askari Chaveri - Azarnoush 2004, 10-12.

Askari Chaveri - Azarnoush 2004, 12.

Askari Chaveri - Azarnoush 2004, 10-12.

Askari Chaveri - Azarnoush 2004.

Askari Chaveri - Azarnoush 2004, 12.

Askari Chaveri - Azarnoush 2004, 15.

Askari Chaveri - Azarnoush 2004, 6.

Askari Chaveri - Azarnoush 2004, 9.
} 
composed of two salty river basins, Mehran in the southwest and Rod-e Shoor (salty river) to the northeast. Until the archaeological survey of Bastak district undertaken by one of the authors in $2007,{ }^{70}$ the area had not been researched. A total of two hundred sites and mounds were noted in Bastak, of which seventy were mounds, fortified sites, settlements and cemeteries, with the rest being made up of structures such as bridges, water storage, qanats, canals, caravansaries, guard towers and mosques. ${ }^{71}$ The seventy sites include four Achaemenid, seventeen Parthian, forty-seven Sasanian (fig. 6) and thirty-eight Islamic sites. ${ }^{72}$ The results of the Lamer and Bastak surveys in many regards are very similar, there is a major resemblance in settlement patterns from the prehistoric through to the Islamic periods. Both regions see an increase in settlements during the Parthian era, with a perceptible peak during the Sasanid era and near collapse in the Islamic era. During the Sasanid period in the Bastak region there is more than a two-fold increase in settlements and fortified sites as compared to the Parthian era. During the Sasanid era there are twentynine settlements in the plains and foothills, and eighteen fortified sites in the mountains of Bastak. $^{73}$ Thirty-two of the Sasanid sites were newly established and some sites measured 10 hectares or more. ${ }^{74}$ One of the settlements in the vicinity of the Mehran river, which is locally known as Shahre Sibeh, was thirty hectares in size and is the largest Sasanid settlement in the Bastak district. ${ }^{75}$ As in Lar and Lamerd, remains of irrigation systems and structures related to water management were discovered in the Bastak district. ${ }^{76}$ In some instances water canals covering up to $10 \mathrm{~km}$ can be seen, and everywhere we see old qanats, locally known as gabri (Zoroastrian), which gives an indication as to the age of these qanats. The location and general shape of fortified sites in the Bastak district, in many cases, are similar. ${ }^{77}$ For example, most of the fortified sites are oval in shape, generally measuring between 0.5 and 1 hectare, and are situated in the mountain nearest to the settlements in the foothills. ${ }^{78}$ With regard to the function of these fortified sites, again we must focus on security, collection of taxes, irrigation and management of settlements, especially due to the lack of trade roads linking these settlements and fortified sites. In other words, in the Bastak district, the increase in settlement numbers is due to the improvement of agricultural and irrigation systems which would not have been possible without governmental support.

\section{SASANIAN TO EARLY ISLAMIC TRANSFORMATION IN THE DISCUSSED AREAS}

In most of the surveyed areas, settlement maps indicate that there was a sharp reduction in sites from the Sasanian to the Early Islamic era. The quantity of sites for both periods, in




the area discussed, is shown in Table 1. In the Early Islamic era the Bastak district lost $80 \%$ of its Sasanian sites - the highest reduction in all of the surveyed areas (fig. 7). Based on Carter's sites table ${ }^{79}$ this reduction in the Bushehr hinterland is approximately $70 \%$ and in the Lar, Lamerd and Dar-olmizan valleys Sasanian sites diminished by 35\%. The only district that apparently shows an increase in site numbers from the Sasanian to Early Islamic Period is the Siraf Highlands. As has already been explained, this was due to the importance of the port at Siraf and its trade route to the north.

In Bastak district, the sudden abandonment of many sites in the foothills including nearly all of the fortified sites of the Sasanain period has been reported.$^{80}$ In many of the Sasanian sites there is no sign of typical Early Islamic sherds. Based on a re-survey of these sites, it is clear that in many cases there was not any water resources in their vicinity. ${ }^{81}$ Indeed, the survival of these sites without a network of channels and water storage structures, capable of transferring water from the remote gorges to the sites, must have been very difficult if not impossible.

Few of the Sasanian sites that show continued occupation from the Sasanian to the Islamic period are located in favourable environmental areas. In other words, the settlement pattern in the Bastak district in the Early Islamic era appears to have returned to that of the pre Parthian period. This situation is also reported in the Lamerd and Mohr plains though not with the degree of collapse that is seen in the Bastak, probably due to the slightly better environmental situation in the Lamerd, Mohr and Darolmizan plains (fig. 8).

Excavations at Siraf have shown that the Sasanian buildings in this port, particularly its castle were destroyed during Arab attacks. However it seems that the site was soon-after used by the invaders. Whitehouse writes that there is a short gap between the destruction of the Sasanian castle and the building of the Siraf mosque above it. General evidence shows that the rise of Siraf in the early Islamic centuries was due to the annihilation of other Persian Gulf ports, in particular Rav Ardeshir in the Bushihr peninsula. Compared to the exceptional situation of Rav Ardeshir, Siraf had never had the capability to convert its Sasanian military role to one of a trade center for a long time. As Whitcomb writes "Once a port (Siraf) ceased to be simply a small fishing village inhabited by the coastal population (historically Arab), its social and economic structure took a quantum leap to an order of complexity which resulted from a range of trade and by a parasitic relationship with at least one urban centre in the hinterland. This was due to the fact that, in economic terms, there was no regional infrastructure of settlements which could give rise naturally to the port as an urban entity was an artificial implantation, becoming a nexus around which a regional settlement system subsequently developed". ${ }^{2}$ Siraf's decline in middle Islamic centuries was an unavoidable process that was merely accelerated by the catastrophic earthquake of 977 AD. ${ }^{83}$

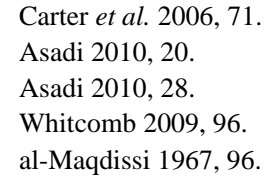


In the Bushehr hinterlands also, Carter writes about the drop in site numbers during the Early Islamic Period, ${ }^{84}$ Carter adds "The study recently undertaken of the Williamson Collection proves this point conclusively, ${ }^{85}$ indicating a drop of over half the number of sites between the $6^{\text {th }}-9^{\text {th }}$ Centuries AD». Williamson himself recognised this trend, having recorded just seven sites of the $9^{\text {th }}-14^{\text {th }}$ Centuries AD period across the Peninsula, with a combined area of 15 ha, compared with 450 ha. ${ }^{86}$ This pattern was established based on a brief inspection of Hazar Mardom on the Bushehr Peninsula during the 2004 season, and casual examination of ceramics from Rishahr. Both sites appear to be devoid of common Umayyad and Abbasid period indicators, such as appliqué decorated Alkaline - Glazed Ware or Samarra Horizon Wares. ${ }^{87}$ As previously noted, at the same time as the Sasanian port of Bushehr fell into decline (Rav Ardeshir), most of the Sasanian sites of the Bushihr plain were also abandoned.

\begin{tabular}{|c|c|c|c|c|}
\hline DISTRICT & $\begin{array}{l}\text { SASANIAN } \\
\text { SITES }\end{array}$ & $\begin{array}{c}\text { EARLY } \\
\text { ISLAMIC } \\
\text { SITES } \\
\end{array}$ & REFERENCES & COMMENTS \\
\hline BUSHEHR & 34 & 9 & Carter et al. 2006 & \\
\hline $\begin{array}{l}\text { MOHR, LAMERD } \\
\text { AND DEZHGAH }\end{array}$ & 30 & 19 & \begin{tabular}{|lll} 
Askari Chaverdi & - \\
Azarnoush 2004 & \\
\end{tabular} & \\
\hline BASTAK & 47 & 10 & Asadi 2010 & \\
\hline $\begin{array}{l}\text { SIRAF } \\
\text { HINTERLANDS }\end{array}$ & 8 & 14 & Whitcomb 2009 & $\begin{array}{l}\text { In Whitcomb's report three sites (two in } \\
\text { Jam Valley and one in Dezhgah), have } \\
\text { been dated to both early Islamic and } \\
\text { Sasanian Periods and here are counted for } \\
\text { both periods too. }\end{array}$ \\
\hline
\end{tabular}

Tab. 1 - Total number of Sasanian and Early Islamic sites in the researched areas.

\section{CONCLUSIONS}

As Wenke has noted «historical and numismatic evidence tells us much about the role of the Parthians and Sasanians in changing the political and social complexion of south west Asia, but it is imperative that archaeological research also be applied to these problems, particularly in analyzing regional settlement, trade, craft production, and other factors that, while neglected textually, seem to be crucial elements in these cultural changes». ${ }^{88}$ Due to the lack of historical records relating to Persian Gulf hinterlands in the Sasanian period, archaeological evidence is the only way to study the changing settlement patterns in this region and time period. The results of the surveyed areas show that, like Susiana and Mesopotamia, during the Sasanid era there was a major increase in settlements in the Persian Gulf hinterlands. Water management in the hinterlands, even today, is a key factor in establishing and sustaining settlements. As already mentioned the increase in

4 Carter et al. 2006, 97.

85 Priestman 2005.

86 Prickett - Williamson 1970

87 Carter et al. 2006, 97.

88 Wenke 1981, 304. 
settlements during the Sasanid period is most likely powered by governmental assistance in land management and irrigation, without which only a small percentage of the hinterlands is suitable for agriculture or settlement. This may well explain the lack of sites prior to the Parthian period, during which time a form of local management and irrigation must have been initiated, which by the time of the Sasanid era was amplified in association with the central government. The presence of central government in the Bastak, Lamer and Siraf hinterlands is evidenced through the presence of multiple fortified sites, close to settlements. The existence of these fortified sites, besides providing security for the settlements was also important for planning and managing the irrigation systems and mobilizing the population to realise governmental plans. It is difficult to estimate the level of farming surpluses in the hinterland areas. Due to the poor soil fertility of most of the discussed areas (except the Bushehr plain), one can postulate that the products were used merely in the interior of Fars province.

There is no detailed research on trade in the Persian Gulf hinterlands during the Sasanid period. Analysis of the surveys undertaken in this region however, do not show any concentration of sites related to the trade roads west of Bushshire plain to the Hormuz strait. The lack of trade routes may in part be due to the east/west trend of the mountains and the difficulty in establishing roads in such terrain, inhibiting the movement of goods from ports such as Siraf. In other parts of the Fars province the evidence for trade relations between sites is not strong either. Whitcomb's research on Ghasre Abu Nasre shows a limited relationship between this and nearby sites. He writes: «The sealings suggest that, at least on an official level, Qasr-i Abu Nasr interacted mostly with Shiraz and secondarily with the district capital, Jur. Connections with other district capitals were very limited, and Qasr-i Abu Nasr did not play the centralised role that Medieval Shiraz did. Rather the sealings suggest that Qasr-i Abu Nasr was a regional town, perhaps typical of many, its influence limited to the plain of Shiraz. The identity of this fortress and its relationship with Shiraz (both the name and the city) must be postponed until the rest of the archaeological evidence from this site has been presented». ${ }^{89}$ If more research in other parts of the Fars province show the same situation it will be possible to suggest that the economy of Fars province during the Sasanid period was based on agriculture with very limited trade between the sites in the interior parts of the province, though to prove this hypothesis, more research, particularly on seals and coins is needed.

Owing to the necessity of governmental management and support for most of the hinterland settlements during the Sasanian Period, their collapse in the Early Islamic period is not surprising. We do not know about the situation created by the arrival of the Arab invaders in detail, but the abandonment of most of the Sasanian fortified sites shows that the Sasanian administrative system that controlled the hinterland districts did not survive. It seems that there was further devastation of sites in important populated centres such as the Bushehr peninsula. Owing to the decline of Rav Ardehir, Siraf's port temporarily replaced it and became famous in the early medieval centuries. As Carter has noted, ${ }^{90}$ the reduction of sites in the Bushehr plain (and in other hinterland districts), contrasted with Whitcomb

89 Whitcomb 1984.

90 Carter et al. 2006, 97. 
and Sumner's hypothesis about Early Islamic Settlements increasing in the interior parts of Fars province. ${ }^{91}$ Although compared to the high reduction of sites in hinterland areas, the rate of abandonment may have been lower in the interior and northern districts of Fars, but the assumption that the number of sites increased in these latter districts after the Sasanian period must be reviewed.

\section{REFERENCES}

ADAMS, R. MCC.

1965 Land Behind Baghdad: A History of Settlement on the Diyala Plains Land behind AsADI, A. Baghdad (The University of Chicago Press), Chicago 1965.

2010 The Settlement Pattern and Land Use in Bastak Plain, Hormozgan Province/Olguy-e Esteghrary va Karbari-e Arazi dar Dasht-e Bastak, Hormozgan (Persian, with English summary): Majale Bastanshenasi va Tarikh (Iranian Journal of Archaeology and History) 45 (2010), pp. 3-32.

ASKARI CHAVERI, A.

2008 Archaeological survey report of Gavbandi district of Hormozgan Province, (Archaeological research center of Iran Archive 2008) (unpublished).

ASKARI CHAVERI, A. - AZARNOUSH, M.

2004 Survey in the Hinterland of the Persian Gulf: Lamerd and Mohr Districts /Barresi-e Bastanshenakhti-e Mohavatehaye Bastani-e Pas Karanehaye Khalij-e Fars: Lamerd va Mohr: Fars” (Persian, with English summary): Majale Bastanshenasi va Tarik (Iranian Journal of Archaeology and History) 36 (2004), pp. 3-19.

Carter, R.A. - Challis, K. - Priestman, S.M.N. - TOFighian, H.

2006 The Bushihr Hinterland Result of the First Season of the Iranian - British Archaeological Survey of Bushehr Province (November - December 2004): Iran 44 (2006), pp. 64-103.

DARYAEE, T.

2003 The Persian Gulf Trade in Late Antiquity: Journal of World History 14 (2003), pp. 1-16.

DE CARDI, B.

1972 Archaeological Survey in Northern Oman: East and West 25 (1972), pp. 9-76.

FISHER, W.B.

1968 Physical Geography: W.B. FISHER (ed.), The Cambridge History of Iran, vol. I: The Land of Iran, Cambridge 1968, pp. 3-110.

GAUBE, $\mathrm{H}$.

1980 Im Hinterland von Siraf: Das Tal von Galledar/Fal und seine Nachbar: Gebiete: Archaeologische Mitteilungen aus Iran 13 (1980), pp. 149-166.

Hojabri-Nobari, A. - KhosRowZadeh, A - Mousavi Kouhpar, S.M. - Vahdatinasab, H.

2001 Trade and Cultural Contacts Between Northern and Southern Persian Gulf during Parthians and Sassanians: A study Based on Pottery From Qeshm Island: International Journal of Humanities and Arts Computing 18/2 (2011), pp. 89-115.

91 Sumner - Whitcomb 1999, 314. 
KIANRAD, $\mathrm{H}$.

2005 The Socioeconomic Conditions of Pars Province From Khosro I Reign to the End of Sasanian Period (531-652 AD)/Ouzae Ejtemaee- Eghtesadi-e Eialat-e Pars az Zaman-e Khosro Anushirvan ta Payan-e Doureye Sasani (652-531AD), MA Diss., University of Tehran, Tehran 2005 (unpublished).

MAQDISI AL

$1967 \quad$ Ahsan al-taqsim fi marifat aqalim, Leiden 1967.

PiACENTINI, V.F.

1985 Ardashir I Papakan and the Wars against the Arabs: Working Hypothesis on the Sasanian Hold of the Gulf: Proceedings of the Society for Arabian Studies 15 (1985), pp. 57-78.

PRiCKETT, M. - Williamson, A.G.

$1970 \quad$ Survey on the Persian Gulf Coast, Oxford 1970.

PRIESTMAN, S.M.N.

2005 Settlement and Ceramics in Southern Iran: An Analysis of the Sasanian and Islamic Periods in the Williamson Collection, MA Diss., University of Durham, Durham 2005 (unpublished).

STEIN, A.

1937 Archaeological Reconnaissance in North Western India and South-Eastern Iran, London 1937.

SUMNER,W.M. - WhiTCOMB, D.

1999 Islamic Settlement And Chronology in Fars: an Archaeological Perspective: Iranica Antiqua XXXIV (1999), pp. 309-324.

WENKE, R.J.

1981 Elymeans Parthians and the Evolution of Empires in Southwestern Iran: Journal of the American Oriental Society 101/3 (1981), pp. 303-315.

Wнітсомв, D.

1979 Trade and Tradition in Medieval Southern Iran, PhD Diss., University of Chicago, Chicago1979.

1984 Qasr-I Abu Nasr and the Gulf: R. Boucharlat (ed.), Arabie Orientale. Mesopotamie et Iran Meridional de L' âge du Fer au début de la Periode Islamique (Editions Recherche sur les civilisations, Mèmoires 37), Paris 1984, pp. 331-337.

2009 The High Valleys: D. WhiteHouSE (ed.), Siraf. History, Topography and Environment (The British Institute of Persian Studies Archaeological Monographs Series I), Oxford 2009, pp. 77-97.

WhiteHOUSE, D. (ed.)

2009 Siraf. History, Topography and Environment (The British Institute of Persian Studies Archaeological Monographs Series I), Oxford 2009.

WhiteHouse, D. - WiLLiamson, A.G.

1973 Sasanian Maritime Trade: Iran 11 (1973), pp. 29-49.

WILLIAMSON, A.G.

1971-1972 Rishahr and the development of trade from the $3^{\text {rd }}$ to the $7^{\text {th }}$ centuries A.D. Chapter 5 in The Maritime Cities of the Persian Gulf and their Commercial Role from the $5^{\text {th }}$ Century to 1507, PhD Diss., Department of Ashmolean Museum Archive, Oxford University, Oxford 1971-1972. 




Fig. 1 - Distribution of Salty plugs on north of Persian Gulf (after Fisher 1968, 31).

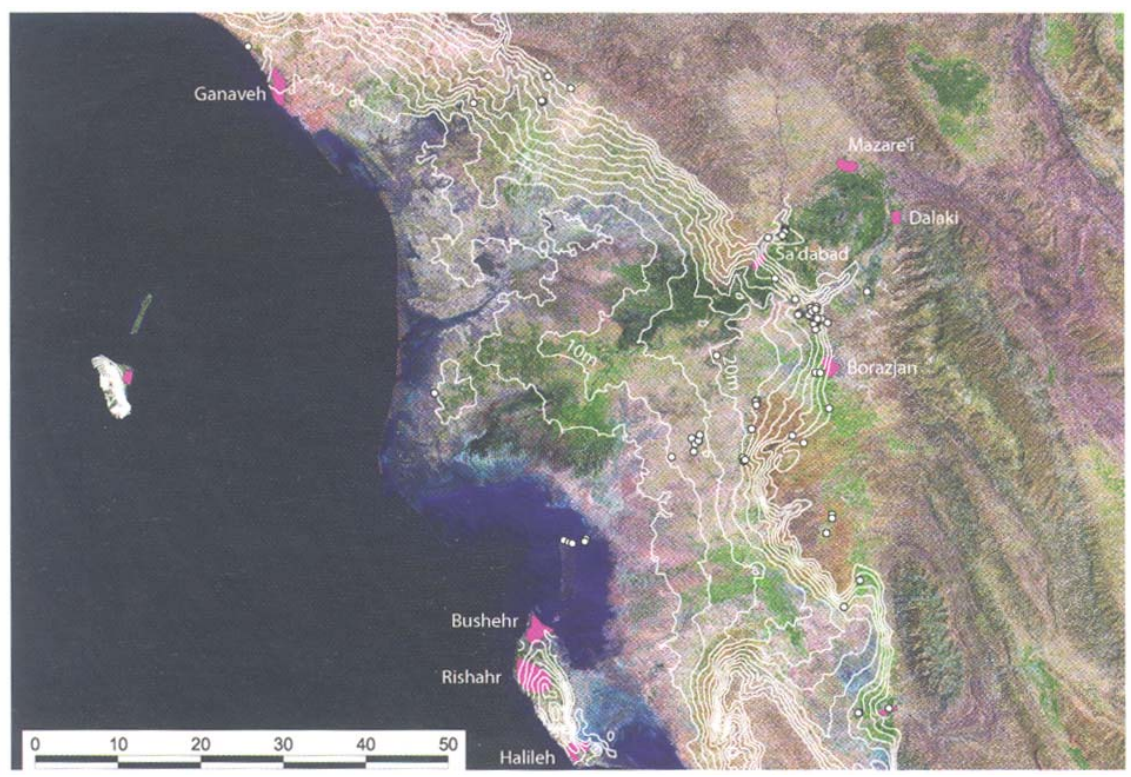

Fig. 2 - Map of Bushihr plain with identified ancient sites (after Carter et al. 2006, 64). 


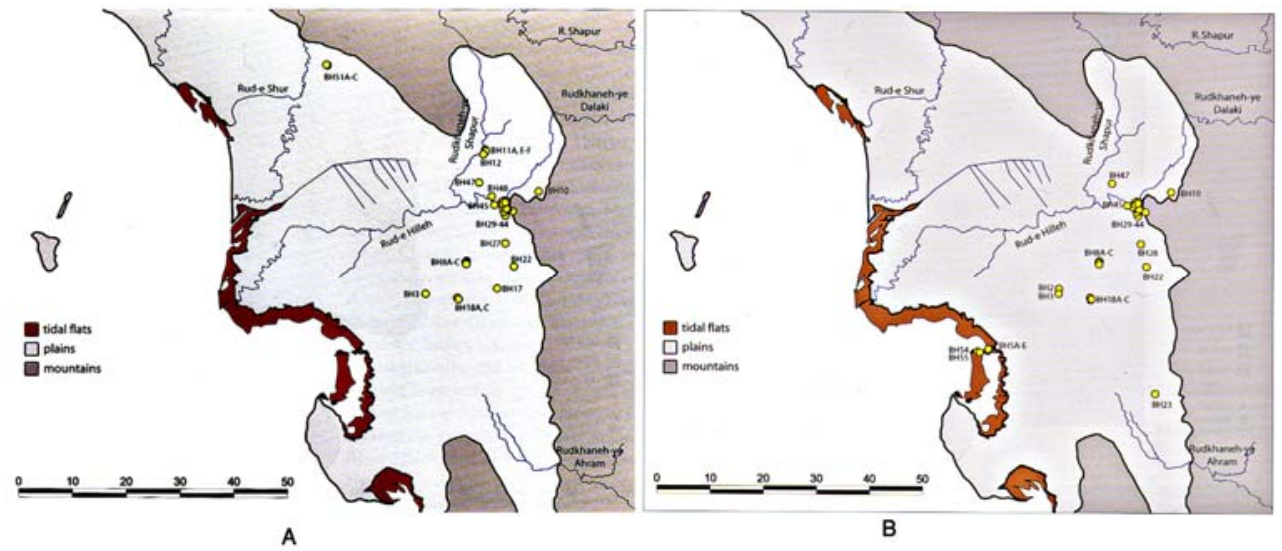

Fig. 3 - Distribution of sites of the Achamenian and Parthian (A) and Sasanian (B) periods in Bushehr Plain (after Carter et al. 2006, 65-66).
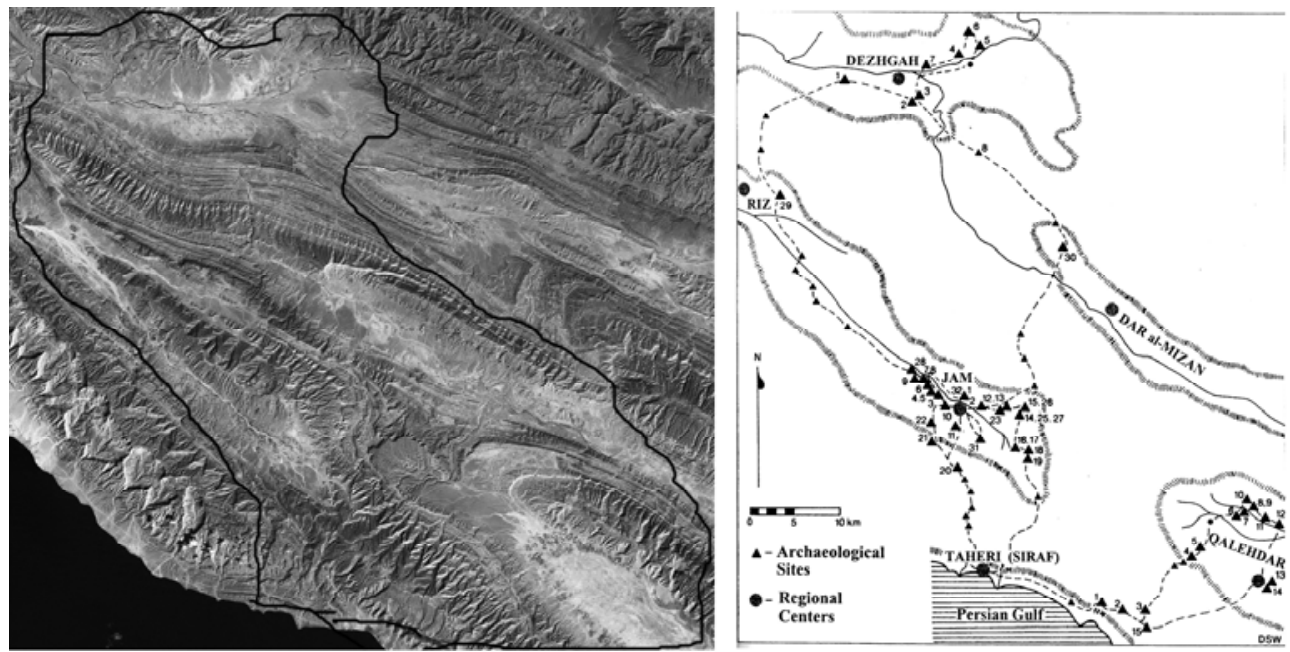

Fig. 4 - Satellite Map of the Siraf hinterlands with the map of identified sites (after Whitcomb 2009, 78). 


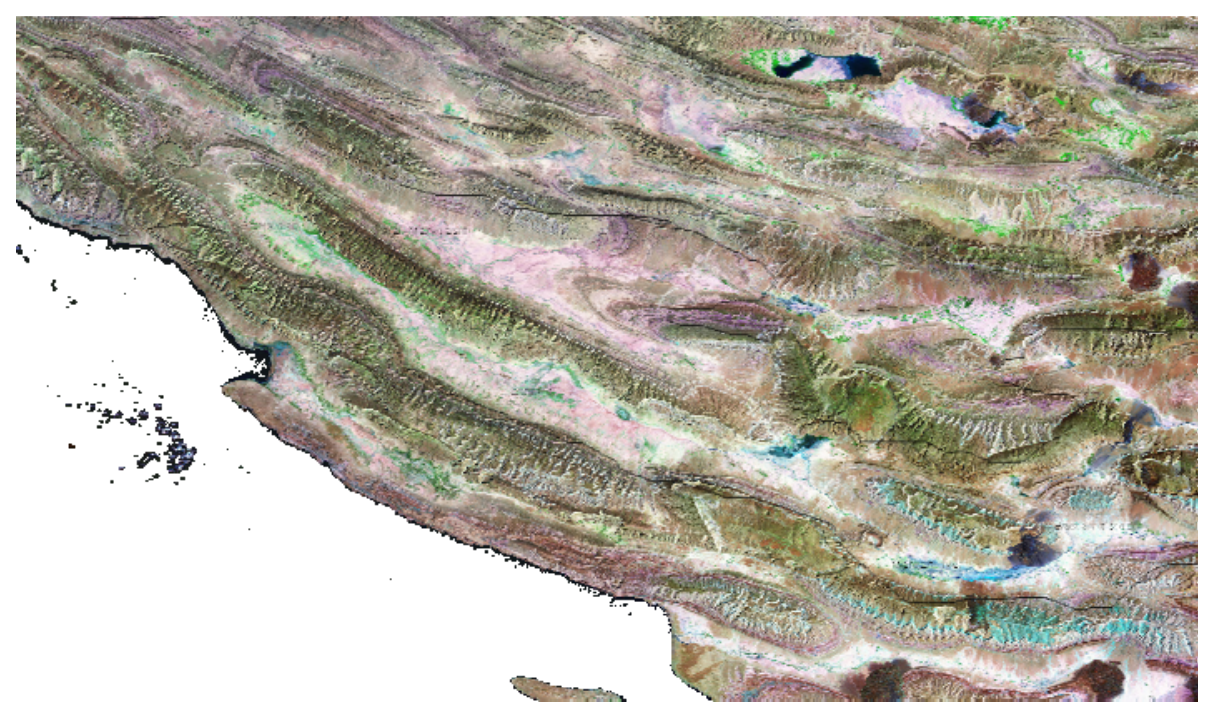

Fig. 5 - Satellite Map of the Lar and Lamerd, Bastak, Siraf and Gavbandi districts.

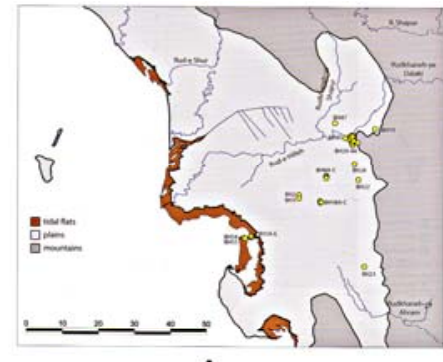

A

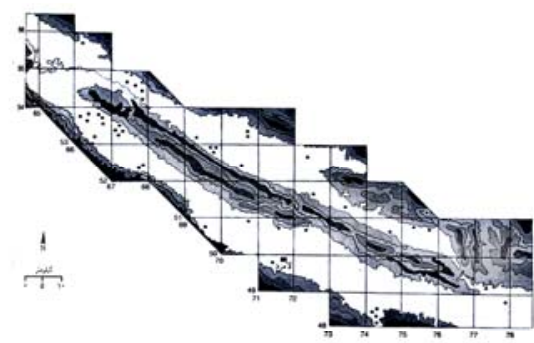

B

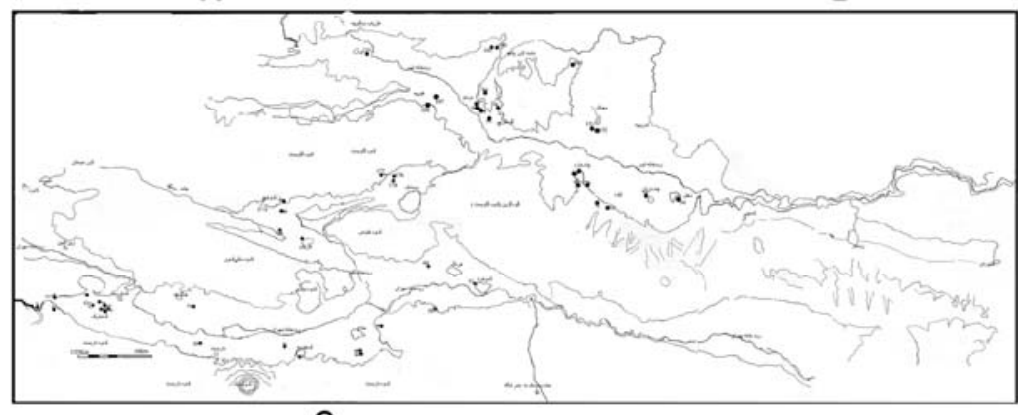

C

Fig. 6 - Distribution of sites of the Sasanian period in Bushehr (after Carter et al. 2006, 66), Lar, Lamerd (after Askari-Chaverdi - Azarnoush 2004, 12) and Bastak (after Asadi 2010, 17) districts. 

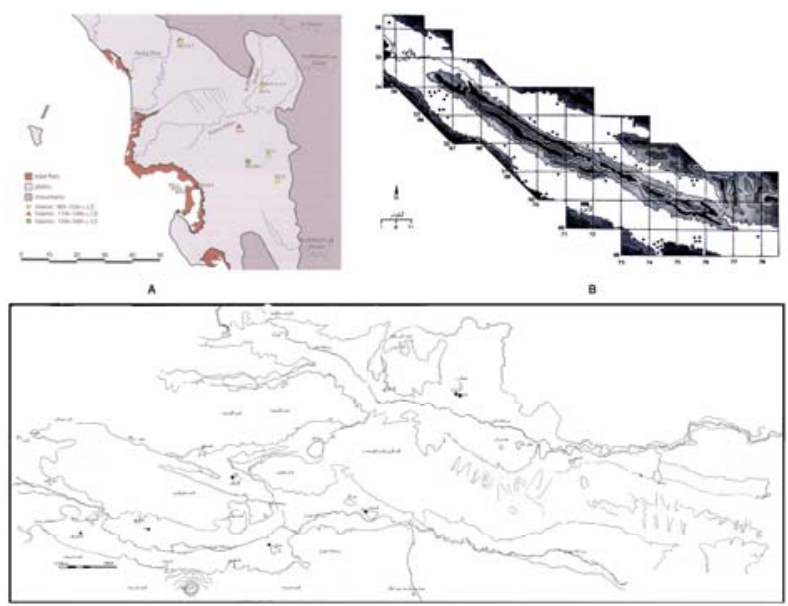

Fig. 7 - Distribution of sites of the Early Islamic period in Bushehr (after Carter et al. 2006, 66), Lar, Lamerd (after Askari-Chaverdi - Azarnoush 2004, 13) and Bastak (after Asadi 2010, 21) districts.
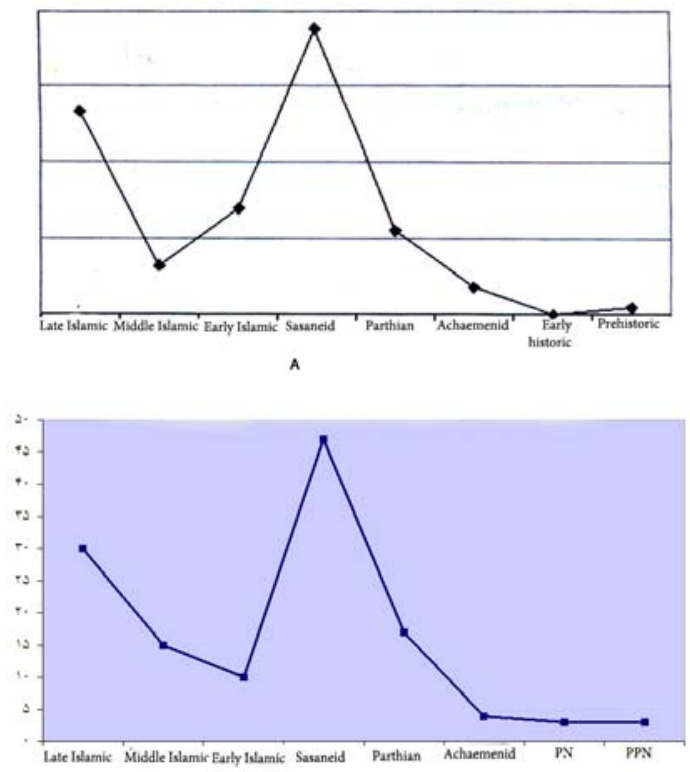

Fig. 8 - The occupation Diagram of Bastak (Asadi 2010, 29) and Lamerd - Mohr (after Askari-Chaverdi - Azarnoush 2004, 14) districts. 